\title{
Combination of Organic and Inorganic Fertilizer Improves Wheat Yields and Soil Properties on Nitisols of Central highlands of Ethiopia
}

\author{
* Girma Chala Zeleke Obsa \\ Holeta Agriculture Research Centre, EIAR, P.O. Box 31, Holeta, Ethiopia
}

\begin{abstract}
A field experiment was conducted for three consecutive cropping seasons (2015-2017) on farmers' fields in Welmera district of Oromiya Regional State with the objective of quantifying the effect of organic and inorganic fertilizers on growth and yield of wheat and soil chemical properties. The treatments included eleven selected combinations of organic and inorganic nutrient sources including farm yard manure, Compost, Nitrogen and Phosphorus application. The experimental design was randomized complete block with three replications. Results showed that wheat yield, yield components and soil chemical properties were significantly affected by the application of organic and inorganic fertilizer sources. The highest wheat(Triticum aestivum L.) grain yield $(4278.1 \mathrm{~kg} / \mathrm{ha})$ and biomass yield $(1385.5 \mathrm{~kg} / \mathrm{ha})$ were obtained from the applications of half doses of compost which is based on recommended $\mathrm{N}$ equivalent and half doses of the recommended nitrogen and phosphorus fertilizers (30kg/ha N and $34.5 \mathrm{~kg} / \mathrm{ha} \mathrm{P}$ that half dose contains) followed by $4269.4 \mathrm{~kg} / \mathrm{ha}$ and $13711.7 \mathrm{~kg} / \mathrm{ha}$ for grain yield and biomass yield, respectively, due to the application of the full recommended $\mathrm{N}$ and $\mathrm{P}$ rates $(60 \mathrm{~kg}$ $\mathrm{N} / \mathrm{ha}$ and $69 \mathrm{~kg} \mathrm{P} / \mathrm{ha}$ )from inorganic fertilizers. Application of organic fertilizer improved organic carbon from $1.08 \%$ to $1.86 \%$, total $\mathrm{N}$ from $0.14 \%$ to $0.28 \%$, available phosphorous from $6.35 \mathrm{ppm}$ to $18.14 \mathrm{pmm}$ and $\mathrm{pH}$ from 4.04 to 5.08. The highest marginal rate of return was obtained from application of $75 \%$ compost (based on equivalent $\mathrm{N}$ rate) plus $25 \% \mathrm{~N}$ and $\mathrm{P}$, which is economically the most profitable on Nitisols of the central Ethiopian highlands.
\end{abstract}

Keywords: Compost, Farm yard manure, Nitisols, Nitrogen, Phosphorus

DOI: $10.7176 / \mathrm{JBAH} / 9-4-02$

\section{INTRODUCTION}

Soil fertility is considered to be the major constraint in the highlands of Ethiopia due to continuous cultivation of these soils without adequate replenishment for long years. This made highland soils deficient in nutrients particularly nitrogen $(\mathrm{N})$ and phosphorous $(\mathrm{P})$. Several studies have indicated widespread nutrient mining as compared to amendments both in quality and quantity resulting in a negative nutrient balance in Africa, (Henao J., et al, 2006; Nkonya, E., 2016). Hence, leading to severe nutrient deficiencies across ecological zones and consequently reducing agricultural productivity. In Ethiopia, the annual net loss of nutrients is estimated to be $40 \mathrm{kgN} \mathrm{ha}^{-1}, 6.6 \mathrm{kgP} \mathrm{ha}^{-1}$ and $33.2 \mathrm{kgK} \mathrm{ha}^{-1}$ (Scoones I., et al, 1995). Nutrient depletion in Ethiopia has several causes. Application of organic fertilizer like crop residues and manure is limited because of competing uses for animal feed and house hold energy. Also problems in the fertilizer sector have restricted the wider use of inorganic fertilizers.

Wheat (Triticum aestivum L.) is one of the most important cereal crops widely grown by small holder framers under rain-fed conditions in Ethiopia. It ranks second next to tef (Eragrostis tef) in mid-altitude and to barley in high altitude areas in terms of area coverage. Productivity is generally low for cereals like maize $\left(2.9 \mathrm{t} \mathrm{ha}^{-1}\right)$, tef $\left(1.3 \mathrm{tha}^{-1}\right)$ and wheat $\left(2.0 \mathrm{t} \mathrm{ha}^{-1}\right)(\mathrm{CSA}, 2012)$. This is due to declining soil fertility, low fertilizer usage, poorly performing and disease susceptible local varieties (Asnakew Woldeab et al., 1991; Jemmal Mohammed, 1994). It is true especially for $\mathrm{N}$ and $\mathrm{P}$ nutrients due to continuous cropping of cereals and low of fertilizer usage (Amsal Tarekegne et al., 2000).

One of the possible options to make use of low rate of chemical fertilizer application without nutrient deficiency of the soil could be recycling of organic wastes. But it is also difficult to attain sustainable productivity neither by inorganic fertilizers nor organic sources alone (Godara AS., 2012). The best remedy for soil fertility management is, therefore, a combination of both inorganic and organic fertilizers, where the inorganic fertilizer provides nutrients and the organic fertilizer mainly increases soil organic matter and improves soil structure and buffering capacity of the soil (Godara AS., 2012). The combined application of inorganic and organic fertilizers is also widely recognized as a way of increasing yield and improving productivity of the soil sustainably (Mahajan A., et al., 2008). There are also some research reports in Ethiopia that revealed the combined effect of organic (Vermicompost, compost and manure) and chemical (NP) fertilizer enhanced the yield of tef and reduced the amount of recommended chemical fertilizer by half (Girma C., et al., 2017). This experiment was therefore, carried out with objective of determining the effect of organic and inorganic fertilizers and their combinations on the yield and yield components of wheat. 


\section{MATERIALS AND METHODS}

\section{Experimental Site}

The experiment was conducted in Welmera, Ada'a Berga and Ejere in Districts West Shewa Zone of Oromia National Regional State for three consecutive cropping seasons (2015, 2016 and 2017). The experiment site are located at $09^{\circ} 03^{\prime} \mathrm{N}$ latitude and $38^{\circ} 30^{\prime} \mathrm{E}$ longitude, 30,60 and $40 \mathrm{~km}$ west of Addis Ababa, at an altitude of about $2400 \mathrm{~m}$ above sea level. The mean annual rainfall of the study area was $1100 \mathrm{~mm}$ of which about $85 \%$ falls from June to September and the rest from March to May. The mean annual temperature is about $14.3^{\circ} \mathrm{c}$, with the mean maximum and minimum temperatures of $21.7^{\circ} \mathrm{c}$ and $6.9^{\circ} \mathrm{c}$ respectively (Holeta Agricultural Research Center Meteorological Report, unpublished data).
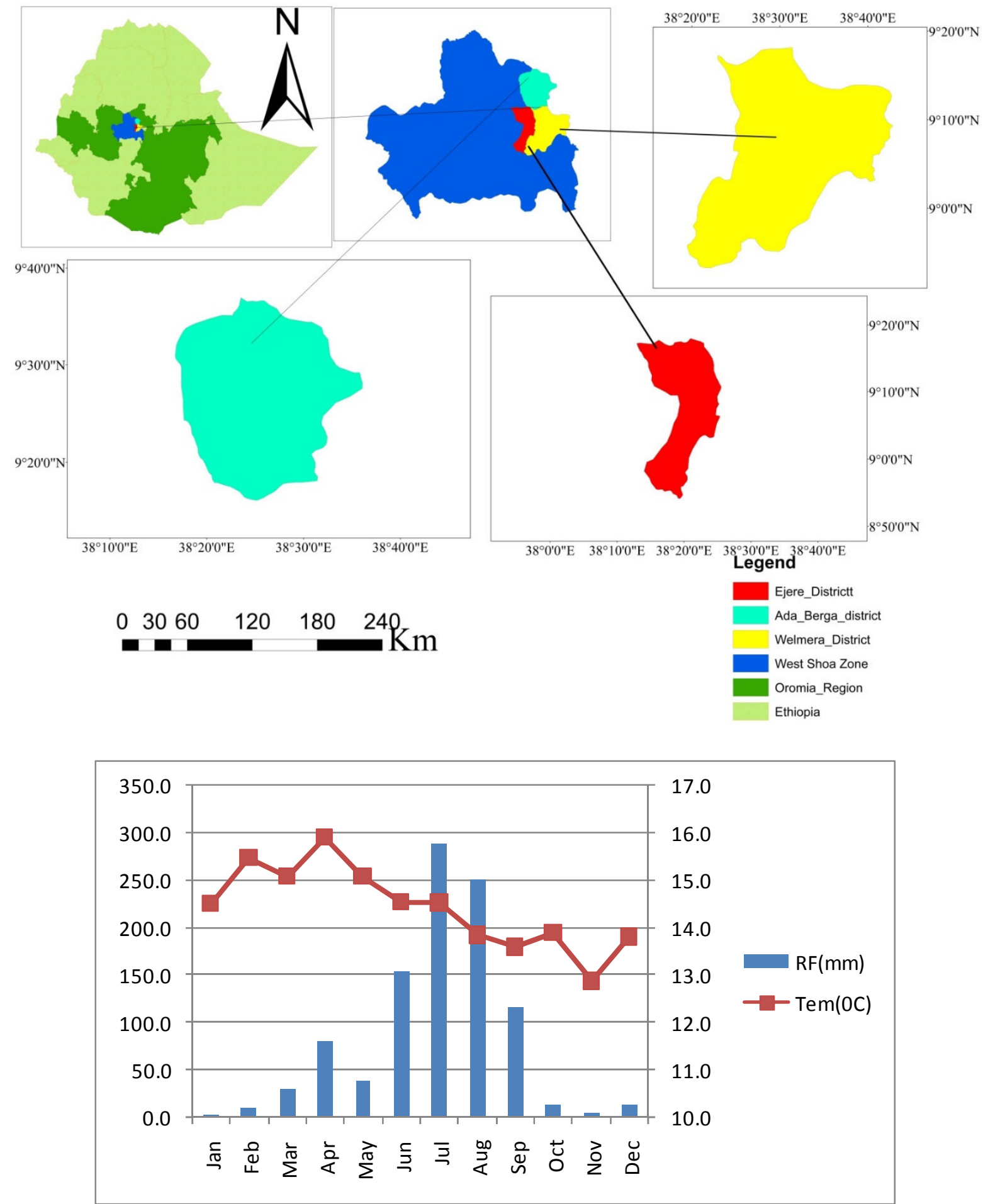

Figure 1: Annual rainfall and average maximum and minimum temperature in Holeta from 2006 to 2015. 
The major soil types of the trial sites are Eutric Nitisols (FAO-WRB, 2006). The crops widely grown in the study area include wheat (Triticum aestivum L.), barley (Hordeum vulgare L.), tef (Eragrostis tef), faba bean (Phaseolus vulgaris L.) and potato (Solanum tuberosum L.). Wheat variety (Digalu) was used as test crop in the experiment. The rates of organic fertilizers applied were calculated based on the recommended $\mathrm{N}$ equivalent rate of the inorganic source for the test crop. These treatment combinations were laid down in Randomized Complete Block Design (RCBD) with three replications.

\section{Treatment Combinations}

$\mathrm{T} 1=$ Negative control

$\mathrm{T} 2=$ Recommended NP-fertilizer $\left(60 \mathrm{~kg} / \mathrm{ha} \mathrm{N}\right.$ and $\left.30 \mathrm{kgP}_{2} \mathrm{O}_{5} / \mathrm{ha}\right)$

$\mathrm{T} 3=$ Recommended FYM based on $\mathrm{N}$ equivalency

$\mathrm{T} 4=$ Recommended Compost based on $\mathrm{N}$ equivalency

T5 $=25 \%$ Recommended FYM based on N equivalency $+75 \%$ Recommended NP

T6 $=50 \%$ Recommended FYM based on N equivalency $+50 \%$ Recommended NP

$\mathrm{T} 7=75 \%$ Recommended FYM based on N equivalency $+25 \%$ Recommended NP

$\mathrm{T} 8=25 \%$ Recommended Compost based on $\mathrm{N}$ equivalency $+75 \%$ Recommended NP

$\mathrm{T} 9=50 \%$ Recommended Compost based on $\mathrm{N}$ equivalency $+50 \%$ Recommended NP

$\mathrm{T} 10=75 \%$ Recommended Compost based on $\mathrm{N}$ equivalency $+25 \%$ Recommended NP

T11 $=33 \%$ FYM $+33 \%$ Compost $+33 \%$ Recommended NP

Samples were collected from well decomposed farmyard manure, compost and vermicompost before they are applied to the field. Then their $\mathrm{N}$ and $\mathrm{P}$ contents were analyzed in the laboratory to determine the rate of application of each treatment, which was based on recommended $\mathrm{N}$ equivalent rate for the test crop. The contents of $\mathrm{N}$ and $\mathrm{P}$ before application in the analyzed samples were $0.88 \% \mathrm{~N}$ and $0.68 \% \mathrm{P}$ for conventional compost both on $55 \%$ dry weight basis and $1.72 \% \mathrm{~N}$ and $0.76 \% \mathrm{P}$ for farm yard manure on $50 \%$ dry weight basis. Manure and compost were applied to the field three weeks before sowing and thoroughly mixed in the upper 15 to $20 \mathrm{~cm}$ soil depth. Nitrogen and $\mathrm{P}$ fertilizers were applied in the form of Urea and DAP respectively. To minimize the loss and increase its efficiency half rate of $\mathrm{N}$ was applied as split at planting and the remaining half was side dressed at tillering stage of the crop whereas all $\mathrm{P}$ rates were applied as basal application during planting time. The seed was drilled at the recommended seed rate of $150 \mathrm{~kg} / \mathrm{ha}$ in row on $10^{\text {th }}, 12^{\text {th }}$ and $16^{\text {th }} \mathrm{July}$ of 2015,2016 and 2017 respectively. All recommended agronomic management practices were carried out during the crop growth period.

\subsection{Data Collection and Analysis}

Composite surface soil samples were collected from experimental fields $(0-20 \mathrm{~cm}$ depth) before treatment application. Similarly, soil samples were collected after harvest of the crop from each plot and then composited by replication to obtain one representative sample per treatment. The collected samples were analyzed for the determinations of $\mathrm{pH}$, organic carbon $(\mathrm{OC})$, total $\mathrm{N}$ and available $\mathrm{P}$. Soil $\mathrm{pH}$ was determined with a $\mathrm{pH}$ electrode at soil: to water ratio of 1:1 (w/v) (Carter, 1993). Organic carbon was determined by the method of Walkley and Black (1934) and total $\mathrm{N}$ using Kjeldahl method (Jackson, 1958). Available P was determined following the procedures of Bray and Kurtz (1945).

Collected plant parameters were grain yield, above ground total biomass, plant height and spike length (average of 5 plants). Grain and biomass yield were measured based on plant samples taken from ten central rows $\left(2 \mathrm{~m} \times 3 \mathrm{~m}=6 \mathrm{~m}^{2}\right)$, plant height measurement (in $\mathrm{cm}$ ) were taken from five randomly selected plants per plot from the soil surface to the tip of the crop at full maturity stage. At harvest, grain yield was adjusted to a moisture content of $12.5 \%$ and grain yield was recorded in $\mathrm{kg} / \mathrm{ha}$.

The agronomic data were subjected to analysis of variance using the GLM procedure using of SAS statistical computer package (SAS, 2002). The total variability for each trait was quantified using separate and pooled analysis of variance over years using the following model (Gomez and Gomoz, 1984):

Pijk $=\mu+Y i+R j(i)+T k+T y(i k)+$ eijk

Where Pijk is the response variable (e.g. grain yield, biomass yield, etc), $\mu=$ grand mean, Yi= effect of the $i^{\text {th }}$ year, $\mathrm{Rj}$ ( $\mathrm{i}$ ) is effect of the $\mathrm{j}^{\text {th }}$ replication (with in thein the $\mathrm{i}^{\text {th }}$ year), Tk is effect of the $\mathrm{K}^{\text {th }}$ treatment with $\mathrm{i}^{\text {th }}$ year TY (ik) is the interaction of $\mathrm{k}^{\text {th }}$ treatment within the $\mathrm{i}^{\text {th }}$ year and eijk is the random error. Duncan multiples range test (DMRT) at 5\% probability level was used to detect differences among means. Finally, economic analysis was done as follows the CIMMYT methodology (1988).

\section{RESULT AND DISCUSSION}

\subsection{Initial Soil Characteristics}

A soil characteristic of the experimental site before applying the treatments is summarized in Table 1. The particle size distribution of the surface layers of the experimental field indicated that the soil had a composition of clay $(72.5 \%)$, silt $(11.25 \%)$ and sand $(16.25 \%)$, which is categorized as clay. The soil $\mathrm{pH}\left(\mathrm{H}_{2} \mathrm{O}\right)$ was 4.8 , indicating 
strongly acidic soil reactions. The preferred range for most crops and productive soils is 4 to 8 (FAO 2000). Thus, the $\mathrm{pH}$ of the experimental soil is almost within the range for productive soils. The organic matter and total nitrogen content of the soil, before planting were found to be $2.26 \%$ and $0.13 \%$, respectively. According to Westerman (1990) rating the organic matter in the soil was medium. Total Nitrogen (TN \%) was rated as low according to the rating by Havlin et al. (1999).

The organic carbon content of the soil before planting was found to be $1.28 \%$. Tekalign (1991) described percentage of carbon content $\mathrm{C}<0.5,0.5-1.5,1.5-3.0,>3.0 \%$ as very low, low, moderate and high, respectively. Hence, the result showed that the total amount of carbon level was low. The cation exchange capacity was $15.2 \mathrm{cmol}_{\mathrm{c}} \mathrm{kg}^{-1}$, which is rated as medium according to Murphy's (2007) rating. The carbon to nitrogen ratio $(\mathrm{C} / \mathrm{N}$ ratio) value was 10.48 , which signify a relatively high rate of mineralization and low rate of $\mathrm{N}$ immobilization. Normally, agricultural soils have a ratio of 10 . The available phosphorus content was $8.65 \mathrm{mg} \mathrm{kg}^{-1}$, which can be rated as low according to the rating by Tekalign (1991).

Table: 1 . Mean of Physico- chemical properties of the $0-20 \mathrm{~cm}$ soil before sowing Particle size Distribution Chemical Properties

\begin{tabular}{cccccccccccc}
\hline $\begin{array}{c}\text { Soil } \\
\text { depth } \\
(\mathrm{cm})\end{array}$ & $\begin{array}{c}\text { Clay } \\
(\%)\end{array}$ & $\begin{array}{c}\text { Silt } \\
(\%)\end{array}$ & $\begin{array}{c}\text { Sand } \\
(\%)\end{array}$ & $\begin{array}{c}\text { Textural } \\
\text { Class }\end{array}$ & $\begin{array}{c}\mathrm{pH} \\
\left(\mathrm{H}_{2} 0\right)\end{array}$ & $\begin{array}{c}\text { TN } \\
(\%)\end{array}$ & $\begin{array}{c}\text { CEC } \\
(\%)\end{array}$ & $\begin{array}{c}\text { OC } \\
(\%)\end{array}$ & $\begin{array}{c}\text { OM } \\
(\%)\end{array}$ & $\begin{array}{c}\text { N/C } \\
(\text { Ratio })\end{array}$ & $\begin{array}{c}\text { Av.P } \\
(\mathrm{ppm})\end{array}$ \\
0.20 & 72.5 & 11.25 & 16.25 & Clay & 5.2 & 0.13 & 15.2 & 1.28 & 2.26 & 10.48 & 8.65 \\
\hline
\end{tabular}

$\mathrm{CL}=$ Clay, $\mathrm{CEC}=$ Cation exchange capacity, $\mathrm{OC}=$ Organic carbon, $\mathrm{OM}=$ Organic carbon, $\mathrm{OM}=$ Organic matter, $\mathrm{TN}=$ Total nitrogen, $\mathrm{C} / \mathrm{N}=$ Carbon to nitrogen ratio, Av.P=Available phosphorus.

\subsection{Soil Properties at the end of the Study}

Soil chemical properties such as $\mathrm{pH}$, organic carbon (OC), total $\mathrm{N}$ and available $\mathrm{P}$ measured for samples taken after harvesting were significantly $(\mathrm{P}<0.01)$ affected by the application of different rate of organic and inorganic fertilizers (Table 2). The result indicated relatively higher $\mathrm{pH}$ levels, OC and nutrient concentrations for plots treated with manure and compost (Table 2). The highest $\mathrm{pH}$ value 5.08 and 5.02 were recorded from full doses of farm yard manure and compost respectively .The average soil $\mathrm{pH}$ of the treatments was about 5.2, which is still acidic. The lowest soil pH (4.04) was recorded from the control plots. Similarly, Ano and Ubochi (2007) reported that application of animal manure and compost increased soil $\mathrm{pH}$.

The values of OC were generally rated as low(Jones, 2003), relatively the highest OC, $1.86 \%$ and $1.82 \%$ were recorded from plots treated with full doses of compost and farm yard manure respectively and the least (1.08\%) was from the control plot (Table 2). Likewise, the total $\mathrm{N}$ and available $\mathrm{P}$ determined after harvesting is rated high (Berhanu D., 1985). As mentioned above for OC, the highest soil total N (0.28\%) was recorded from plots treated with full doses of compost. The lowest soil $\mathrm{N}$ content $0.14 \%$ was obtained from the control plots as usual. Similarly, the highest soil available P (18.14 ppm) was recorded from plots treated with one-fourth of compost $+50 \%$ recommended Nitrogen and phosphorus fertilizers. But, all plots which received fertilizer, either alone or in combination did not significantly differ one from the other except the control plot which gave lower P values.

The above findings are in line with the reports of Eghball et al. (2004) that the residual effects of manure and compost applications significantly increased electrical conductivity, $\mathrm{pH}$ levels and plant available $\mathrm{P}_{\text {and }} \mathrm{NO}_{3}-\mathrm{N}$ concentrations where the lowest $\mathrm{pH}$ and nutrient content were observed on plots not treated with organic fertilizer. Sharma et al. (1990) also indicated that the use of organic fertilizer might have made the soil more porous and pulverized, to allow better root growth and development, thereby resulting in higher root cation exchange capacity (CEC). According to Sanchez (1976) the application of organic fertilizer directly influences the availability of native or applied phosphorus. Generally, the above results indicate that integrated use of nutrient sources have significant improvement in the overall condition of the soil as well as agricultural productivity if best alternative option is adopted in the area. 
Table 2: The effect of organic and inorganic fertilizer application on soil chemical properties analyzed for samples after harvest of the crops

\begin{tabular}{|c|c|c|c|c|c|c|c|c|}
\hline \multirow[t]{2}{*}{ Treatments } & \multirow[t]{2}{*}{$\mathrm{pH}\left(\mathrm{H}_{2} \mathrm{O}\right)$} & \multirow[t]{2}{*}{$\begin{array}{l}\text { Nitrogen } \\
(\%)\end{array}$} & \multirow[t]{2}{*}{$\begin{array}{l}\text { Phosphorous } \\
\text { (ppm) }\end{array}$} & \multirow[t]{2}{*}{$\begin{array}{l}\mathrm{OC} \\
(\%)\end{array}$} & \multicolumn{4}{|c|}{$\begin{array}{c}\text { Exchangeable bases } \\
\text { (meq/100g) }\end{array}$} \\
\hline & & & & & $\mathrm{Ca}$ & $\mathrm{Mg}$ & $\mathrm{K}$ & $\mathrm{Na}$ \\
\hline Negative & 4.04 & 0.14 & 6.35 & 1.08 & 12.339 & 4.025 & 0.446 & 0.019 \\
\hline R NP & 4.16 & 0.18 & 9.17 & 1.16 & 10.594 & 3.425 & 0.445 & 0.020 \\
\hline FYM & 5.02 & 0.26 & 13.69 & 1.82 & 11.873 & 3.823 & 0.505 & 0.043 \\
\hline Compost & 5.08 & 0.28 & 14.26 & 1.86 & 10.619 & 4.284 & 0.482 & 0.020 \\
\hline $25 \% \mathrm{FYM}+75 \% \mathrm{RNP}$ & 5.02 & 0.24 & 16.1 & 1.72 & 11.060 & 3.804 & 0.438 & 0.019 \\
\hline $50 \%$ FYM + 50\% R NP & 4.8 & 0.23 & 12.75 & 1.48 & 11.549 & 4.412 & 0.423 & 0.025 \\
\hline $75 \%$ FYM + 25\% RNP & 4.72 & 0.26 & 14.22 & 1.62 & 11.233 & 4.242 & 0.442 & 0.020 \\
\hline $25 \%$ Comp $+75 \%$ R NP & 4.8 & 0.22 & 18.14 & 1.64 & 12.438 & 4.299 & 0.436 & 0.017 \\
\hline $50 \%$ Comp $+50 \%$ RNP & 4.82 & 0.22 & 15.28 & 1.62 & 10.704 & 3.231 & 0.410 & 0.020 \\
\hline $75 \%$ Comp + $25 \%$ R NP & 4.68 & 0.21 & 12.42 & 1.58 & 11.875 & 4.623 & 0.454 & 0.017 \\
\hline $\begin{array}{l}33 \% \text { FYM + 33\% Comp } \\
+33 \% \text { R NP }\end{array}$ & 4.8 & 0.24 & 14.13 & 1.66 & 11.596 & 4.455 & 0.435 & 0.022 \\
\hline Mean & 4.72 & 0.225 & 13.32 & 1.57 & 11.444 & 4.057 & 0.447 & 0.022 \\
\hline
\end{tabular}

\subsection{Effects of integrated nutrient application on wheat yield and yield components}

The combined analysis of variance over three years revealed that the effect of cropping season was highly significant $(p<0.01)$ on flowering date, plant height, grain and biomass yield of wheat and significant $(p<0.05)$ on plant height, day to physiological maturate, spike length, thousand seed weight and grain yield. This study clearly indicated that productivity of wheat was significantly affected by different treatment applied. Thus, applications of inorganic and organic nutrient sources either alone or in combination had a significant $(\mathrm{p}<0.05)$ effect on all parameters, such as grain yield, biomass yield, plant height, physiological maturity, flowering date, spike length and thousand seed weight of wheat.

The highest wheat spike length, grain and biomass yield $(10.77 \mathrm{~cm}, 4278.1 \mathrm{~kg} / \mathrm{ha}$ and $1385.5 \mathrm{~kg} / \mathrm{ha}$ respectively) were obtained from the application of $50 \%$ compost (based on $\mathrm{N}$ equivalence ratio) and half the recommended rate of $\mathrm{N}$ and $\mathrm{P}$ followed by full dose of recommended rate of $\mathrm{N}$ and $\mathrm{P}$ from inorganic fertilizer resulting in $4269.4 \mathrm{~kg} / \mathrm{ha}$ grain and $13711.7 \mathrm{~kg} / \mathrm{ha}$ biomass yields respectively. The negative treatment was taken the highest thousand seed weight and flowering date $(42.52 \mathrm{~cm}$ and 75.75 day) respectively. The rest set of treatments had given inferior yields under all tested parameters and the result from the control plot was also the least as usual (Table 3).

Table 3: Effects of organic and inorganic fertilizers application on Wheat yield and yield components

\begin{tabular}{|l|l|l|l|l|l|l|l|}
\hline Treatments & GY(kg/ha) & BY(kg/ha) & Pht(cm) & Sp(cm) & DPM & TSW & FD \\
\hline Negative & $2287.8^{\mathrm{e}}$ & $8486.6^{\mathrm{f}}$ & $99.08^{\mathrm{d}}$ & $8.07^{\mathrm{d}}$ & $154.5^{\mathrm{a}}$ & $42.52^{\mathrm{a}}$ & $75.75^{\mathrm{a}}$ \\
\hline R NP & $4269.4^{\mathrm{a}}$ & $13711.7^{\mathrm{ab}}$ & $111.38^{\mathrm{a}}$ & $9.7^{\mathrm{b}}$ & $142.3^{\mathrm{b}}$ & $40.75^{\mathrm{b}}$ & $69.58^{\mathrm{e}}$ \\
\hline FYM & $3090.8^{\mathrm{d}}$ & $10463.5^{\mathrm{de}}$ & $106.0^{\mathrm{b}}$ & $9.7^{\mathrm{b}}$ & $155.3^{\mathrm{a}}$ & $42.65^{\mathrm{a}}$ & $72.83^{\mathrm{b}}$ \\
\hline Compost & $3052.0^{\mathrm{d}}$ & $9782.1^{\mathrm{e}}$ & $101.82^{\mathrm{c}}$ & $9.03^{\mathrm{c}}$ & $155.25^{\mathrm{a}}$ & $42.75^{\mathrm{a}}$ & $72.67^{\mathrm{b}}$ \\
\hline $25 \%$ FYM + 75\% RNP & $3905.0^{\mathrm{ab}}$ & $12155.7^{\mathrm{c}}$ & $107.2^{\mathrm{b}}$ & $10.0^{\mathrm{ab}}$ & $143.25^{\mathrm{b}}$ & $42.13^{\mathrm{ab}}$ & $71.17^{\mathrm{cd}}$ \\
\hline $50 \%$ FYM + 50\% R NP & $3970.2^{\mathrm{ab}}$ & $12566.6^{\mathrm{bc}}$ & $107.4^{\mathrm{b}}$ & $10.2^{\mathrm{ab}}$ & $154.3^{\mathrm{a}}$ & $42.2^{\mathrm{ab}}$ & $72.0^{\mathrm{bc}}$ \\
\hline $75 \%$ FYM + 25\% RNP & $3594.8^{\mathrm{bc}}$ & $11589.3^{\mathrm{cd}}$ & $107.5^{\mathrm{b}}$ & $10.1^{\mathrm{ab}}$ & $153.9^{\mathrm{a}}$ & $41.92^{\mathrm{ab}}$ & $72.58^{\mathrm{b}}$ \\
\hline $25 \%$ Comp + 75\% R NP & $4177.9^{\mathrm{a}}$ & $13665.8^{\mathrm{ab}}$ & $110.8^{\mathrm{a}}$ & $10.2^{\mathrm{ab}}$ & $143.58^{\mathrm{b}}$ & $40.65^{\mathrm{b}}$ & $70.75^{\mathrm{d}}$ \\
\hline $50 \%$ Comp + 50\% RNP & $4278.1^{\mathrm{a}}$ & $1385.5^{\mathrm{a}}$ & $110.3^{\mathrm{a}}$ & $10.77^{\mathrm{a}}$ & $153.75^{\mathrm{a}}$ & $41.62^{\mathrm{ab}}$ & $72.08^{\mathrm{bc}}$ \\
\hline $75 \%$ Comp + 25\% R NP & $3378.0^{\text {cd }}$ & $11356.7^{\text {cd }}$ & $106.6^{\mathrm{b}}$ & $10.13^{\mathrm{ab}}$ & $153.8^{\mathrm{a}}$ & $41.58^{\mathrm{ab}}$ & $72.42^{\mathrm{bc}}$ \\
\hline $\begin{array}{l}33 \% \text { FYM }+33 \% \text { Comp }+ \\
33 \% \text { R NP }\end{array}$ & $3293.0^{\text {cd }}$ & $11436.7^{\text {cd }}$ & $105.6^{\mathrm{b}}$ & $10.0^{\mathrm{ab}}$ & $154.8^{\mathrm{a}}$ & $42.45^{\mathrm{a}}$ & $72.92^{\mathrm{b}}$ \\
\hline DMRT & 354.97 & 1208.3 & 2.325 & 0.683 & 2.73 & 1.43 & 1.119 \\
\hline CV $(\%)$ & 12.2 & 12.7 & 2.8 & 8.6 & 2.2 & 4.2 & 1.9 \\
\hline
\end{tabular}

Therefore, the result of this study has clearly indicated that it is possible to fairly produce wheat through integrated nutrient application approach, rather than applying nutrient from one source. In line with the current result, research findings of Mamo et al., (2001) and Agegnehu (2012) indicated that wheat has showed significance response to the integrated soil fertility management treatments containing both organic and inorganic forms under farmers' field condition that they could be considered as alternative options for sustainable soil and crop productivity in the degraded highlands of Ethiopia. Moreover, the crop has responded differently to application of $\mathrm{N}$ and $\mathrm{P}$ on different soil types. 


\section{Economic Analysis}

As farmers attempt to evaluate the economic benefits of shift in practice, partial budget analysis was done to identify the rewarding treatments. Yield from on farm experimental plots was adjusted downward by $10 \%$ for management difference to reflect the difference between the experimental yield and the yield that farmers could expect from the same treatment. The economic analysis was calculated as follows: $\mathrm{TVC}=$ the sum of cost input $(\mathrm{N}$ fertilizer price), $\mathrm{AGY}=$ grain yield $\times 10 / 100 ; \mathrm{AGY}=$ total grain yield minus adjusted grain yield, $\mathrm{GB}=$ adjusted grain yield $\mathrm{x}$ total variable cost, $\mathrm{NB}=$ gross benefit-total variable cost, $\mathrm{MRR} \%=$ change of net benefit divided to change of total variable cost x 100 . Three years average market grain price of wheat ( $15 \mathrm{birr} / \mathrm{kg}$ ), farm-gate price of $\mathrm{N}$ and $P$ fertilizers (12 and $15 \mathrm{birr} / \mathrm{kg}$ ) respectively and labour for sprayer valued at $50 \mathrm{birr} /$ person-day were used.

Table 4: Marginal analysis of organic and inorganic fertilizer effects on barley 2015-2017

\begin{tabular}{|c|c|c|c|c|c|c|c|c|}
\hline Treatments & $\begin{array}{l}\mathrm{GY} \\
\mathrm{kg} / \mathrm{ha}\end{array}$ & $\begin{array}{l}\mathrm{AD} \\
\mathrm{GY} \\
\mathrm{kg} / \mathrm{ha}\end{array}$ & $\begin{array}{l}\text { Fert } \\
\text { cost }\end{array}$ & $\begin{array}{l}\text { Labour } \\
\text { cost }\end{array}$ & TVC & Gross B & $\begin{array}{l}\text { Net } \\
\text { Benefit }\end{array}$ & $\begin{array}{l}\text { MRR } \\
(\%)\end{array}$ \\
\hline Negative & 2287.8 & 2059.0 & 0 & 0 & 0 & 28826.3 & 28826.28 & 0 \\
\hline R NP & 4269.4 & 3842.5 & 3810 & 0 & 3810 & 53794.4 & 49984.44 & 555.3 \\
\hline FYM & 3090.8 & 2781.7 & 0 & 450 & 450 & 38944.1 & 38494.08 & 341.9 \\
\hline Compost & 3052 & 2746.8 & 0 & 1000 & 1000 & 38455.2 & 37455.2 & $\mathrm{D}$ \\
\hline $25 \%$ FYM + 75\% RNP & 3970.2 & 3573.2 & 1905 & 250 & 2155 & 50024.5 & 47869.52 & $\mathrm{D}$ \\
\hline $50 \% \mathrm{FYM}+50 \% \mathrm{R} \mathrm{NP}$ & 3594.8 & 3235.3 & 950 & 167 & 1117 & 45294.5 & 44177.48 & 355.7 \\
\hline $75 \%$ FYM + 25\% RNP & 4177.9 & 3760.1 & 2857.5 & 250 & 3107.5 & 52641.5 & 49534.04 & 269.1 \\
\hline $25 \%$ Comp $+75 \%$ R NP & 4278.1 & 3850.3 & 1905 & 500 & 2405 & 53904.1 & 51499.06 & $\mathrm{D}$ \\
\hline $50 \%$ Comp $+50 \%$ RNP & 3378 & 3040.2 & 952.5 & 750 & 1702.5 & 42562.8 & 40860.3 & 1514.4 \\
\hline $75 \%$ Comp $+25 \%$ R NP & 3293 & 2963.7 & 1270 & 500 & 1770 & 41491.8 & 39721.8 & $\mathrm{D}$ \\
\hline $\begin{array}{l}33 \% \text { FYM }+33 \% \text { Comp }+ \\
33 \% \text { R NP }\end{array}$ & 2287.8 & 2059.0 & 3373.3 & 250 & 2155 & 40479.5 & 38324.5 & 112.1 \\
\hline
\end{tabular}

The economic analysis further revealed that the application of $75 \%$ of compost plus $25 \%$ recommended $\mathrm{N}$ and $\mathrm{P}$ fertilizers provided the highest marginal rate of the return (MRR) of 1514.4\% (Table 4) suggesting for one birr invested in wheat production, the producer would collect birr 15.14 after recovering his investment. Since the MRR assumed in this study was $100 \%$, the treatment with application of $75 \%$ of compost and $25 \%$ RNP gave an acceptable MRR. Therefore, the application $75 \%$ compost (based on $\mathrm{N}$ equivalent rate) and $25 \%$ recommended $\mathrm{N}$ and $\mathrm{P}$ fertilizers mentioned above is found economical to be recommended on Nitisols of the study area and similar locations in the central highlands of Ethiopia.

\section{CONCLUSION}

The result demonstrate that the three years result were significantly different from each other most probably attributed to season differences and the carry over effect of the previous year fertilizer application as the plots were fixed during the experimental period. Integrated use of organic and inorganic fertilizers plays a critical role in a both short- term nutrient availability and longer- term maintenance of soil organic matter and sustainability crop productivity in most smallholder farming systems in the tropics. The effects of organic nutrient source such as farm yard manure are not immediate as inorganic nutrient sources, but their effects are long-lasting and sustainable. Interventions to increase nutrient use efficiency and reduce NP losses to the environment must be accomplished at the farm level through a combination of improved technologies and carefully crafted local policies that promote the adoption of improved $\mathrm{N}$ management practices while sustaining yield increases. Improved fertilizer products play an important role in the global quest for increasing nutrient use efficiency. The results of soil analysis after harvesting revealed that application organic fertilizer improved soil $\mathrm{pH}, \mathrm{OC}, \mathrm{N}$ and available $\mathrm{P}$ and exchangeable cations. The three year result showed that the integrated application of organic and inorganic fertilizers improved productivity of wheat as well as the fertility status of the soil. Applications of organic fertilizers not only improve the nutrient content of soils, but also improve the physical and biological condition of soils.

\section{ACKNOWLEDGEMENTS}

The authors acknowledge the Ethiopian Institute of Agricultural Research (EIAR) and would like to express their appreciation to Mr. Haile Beza, Mr. Beyene Offa, Mr. Tesfaye Negash, Mrs. Kessach Birhanu, and Mrs.Tigist Feyisa for their technical assistance during the execution of the experiments under field condition. Appreciation is also due for the services of the analytical soil laboratory of Holeta Agricultural Research Centre.

\section{REFERENCES}

Amsal Tarekegn, D.G. Tanner, Taye Tesema and Chanyalew Mandefro, 2000. Agronomic and economic evaluation of the on-farm $\mathrm{N}$ and $\mathrm{P}$ response of bread wheat grown on two contrasting soil types in cetral 
Ethiopia. pp. 239-252. The Eleventh Regional Wheat Workshop for Eastern, Central and Southern Africa. CIMMYT, Addis Ababa, Ethiopia.

Ano A.O. and C.I. Ubochi, 2007. Neutralization of soil acidity by animal manures; mechanism of reaction. African Journal of Biotechnology 6: 364-368.

Asnakew Woldeab, Tekalign Mamo, Mengesha Bekele and Tefera Ajamo, 1991. Soil fertility management studies on wheat in Ethiopia. Pp. 137- 172. In: Hailu Gebre Mariam, D.G. Tanner and Mengistu Hulluka (eds.). Wheat Research in Ethiopia: A historical perspective. IAR/CIMMYT, Addis Ababa.

Berhanu D (1985). The physical criteria and their rating proposed for land evaluation in the highland region of Ethiopia. Land Use Planning and Regulatory Department, Ministry of Agriculture, Addis Ababa, Ethiopia.

Bray R.H., Kurz L. T. 1945. Determination of total, organic and available forms of phosphorous in soil. Soil science Journal. 59:39-45 Ankerman, D, Large R. (SD) Agronomy Handbook, Soil and Plant Analysis, A and L. Agricultural Laboratories. Memphis, USA

Central Statistical Agency. 2012. Agricultural Sample Survey on Crop and Livestock Product Utilization.

CIMMYT (International Maize and Wheat research Center).1988. From agronomic data to farmers' recommendation: Economic analysis training manual. Completely revised edition. D.F. Mexico.

Eghball B, D. Ginting and J.E .Gilley, 2004. Residual effects of manure and compost applications on corn production and soil properties. Agronomy Journal. 96: 442- 447.

Getachew Agegnehu, Angaw Tsigie and Agajie Tesfaye, 2012. Evaluation of crop residue retention, compost and inorganic fertilizer application on barley productivity and soil chemical properties in the central Ethiopia highland. Ethiopia. J. Agric. Sci. 22: 45-61.

Girma Chala and Gebreyes Gurmu (2017). Effect of Organic and Inorganic Fertilizers on Growth and Yield of Wheat (Triticum aestivum L.) in the Central Highlands of Ethiopia. Ethiop. J. Natural Res. 14(2) 55- 66

Godara AS, Gupta US, Singh R (2012) Effect of integrated nutrient management on herbage, dry fodder yield and quality of oat (Avena sativa L.). Forage Research 38: 59-61.

Gomez, K.A., Gomez, A.A.1984. Statistical procedure for agricultural research $2^{\text {nd }}$ (Ed.). A Wiley Inter-Science Publication, New York.

Henao J. and C. Banante, 2006. Agricultural Production and Soil Nutrient Mining in Africa Implications for Resource Conservation and Policy Development: Summary An International Center for Soil Fertility and Agricultural Development; IFDC

Jackson, M.L., 1958. Soil chemical analysis. Prentice Hall, Inc., Englewood Cliffs. Newjersy.

Jemmal Mohammed. 1994. Performance of wheat genotypes under irrigation in Awash valley, Ethiopia. African Crop Science Journal 2: 145-151.

Jones, J.B. 2003. Agronomic hand book: management of crops, soils, and their fertility. CRC Press, Boca Raton London New York Washington, D.C. 450pp.

Mahajan A, Bhagat RM, Gupta RD (2008) Integrated nutrient management in sustainable rice-wheat cropping system for food security in India. Journal of Agriculture 6: 29-32.

Mamo Tekalign, Erkossa Teklu, Tulema Balesh, 2001. Soil fertility and plant nutrition research on tef in Ethiopia. In: Tefera Hailu, Belay Getachew, M. Sorrels (Eds.). Tef research and development in Ethiopia. Ethiopian Institute of Agricultural Research, Addis Ababa, Ethiopia, pp: 191-201.

Nkonya, E. Anderson, W., Kato, E., Koo, J., Mirzabaev, A., von Braun, J. and Meyer, S. (2016). Global cost of land degradation. In: Nkonya E. Mirzabaev A. and von Braun J. (eds). Economics of Land Degradation and Improvement. Springer, Netherlands.

Sanchez, P.A., Izac A.M., Valencia I. and Pieri C. 1996. Soil Fertility Replenishment in Africa: A Concept Note. In: Proceeding of the workshop on developing African agriculture: Achieving a Greater Impact from Research Investments. September 26-30, 1995. Addis Ababa, Ethiopia. 200-207p.

SAS Institute, 2002. SAS User's Guide, Statistics version 8.2 (Ed.). SAS Inst., Cary, NC, USA.

Scoones, I., Toulmin, C., 1995. Socio-Economic Dimensions of Nutrient Cycling in Agro pastoral Systems in Dry land Africa, pp. 353-370. In: Powell, J., Fernandez-Rivera, S, Williams, T., Renard, C. (Eds.),. Livestock and Sustainable Nutrient Cycling in Mixed Farming Systems in Sub-Saharan Africa. ILCA, Addis Ababa.

Sharma P.K., T.S. Verma, and J.P. Gupta, 1990. Ameliorating effects of phosphorus, lime and animal manure on wheat yield and root cation exchange capacity in degraded Alfisols of North- West Himalayas. Fertilizer Research 23: 7-13.

Walkley, A. and C.A. Black, 1934. An examination of Degtjareff method for determining soil organic matter and the proposed modification of the chromic acid titration method. Journal of Soil Science, 37: 29-38. 